\title{
Current status and achievements of Polish haemato-oncology
}

Sebastian Giebel ${ }^{1}$, Grzegorz Basak², Maria Bieniaszewska ${ }^{3}$, Tomasz Czerw ${ }^{1}$, Anna Czyż ${ }^{4}$, Joanna Drozd-Sokołowska ${ }^{2}$, Dominik Dytfeld ${ }^{5}$, Krzysztof Giannopoulos ${ }^{6}$, Lidia Gil ${ }^{5}$, Grzegorz Helbig ${ }^{7}$, Jerzy Hołowiecki ${ }^{1}$, Iwona Hus ${ }^{8}$, Krzysztof Jamroziak ${ }^{8,9}$, Wiesław W. Jędrzejczak ${ }^{2}$, Wojciech Jurczak ${ }^{10}$, Artur Jurczyszyn ${ }^{11}$, Ewa Lech-Marańda ${ }^{8}$, Krzysztof Lewandowski $^{5}$, Krzysztof Mądry ${ }^{2}$, Monika Prochorec-Sobieszek ${ }^{12}$, Tadeusz Robak ${ }^{13}$, Tomasz Sacha ${ }^{11}$, Małgorzata Sokołowska-Wojdyło ${ }^{14}$, Michał Szymczyk ${ }^{9}$, Jan Walewski ${ }^{9}$, Agnieszka Wierzbowska ${ }^{13}$, Dariusz Wołowiec ${ }^{4}$, Tomasz Wróbel ${ }^{4}$, Jan Maciej Zaucha ${ }^{3}$, Jan Styczyński ${ }^{15, *}$

${ }^{1}$ Department of Bone Marrow Transplantation and Oncohaematology, Maria Skłodowska-Curie National Research Institute of Oncology Gliwice Branch, Gliwice, Poland

${ }^{2}$ Department of Haematology, Transplantology and Internal Medicine, Medical University, Warsaw, Poland

${ }^{3}$ Department of Haematology and Transplantology, Medical University, Gdańsk, Poland

${ }^{4}$ Department of Haematology, Medical University, Wrocław, Poland

${ }^{5}$ Department of Haematology, Poznan University of Medical Sciences, Poznań, Poland

${ }^{6}$ Department of Experimental Haematooncology, Medical University of Lublin, Lublin, Poland

${ }^{7}$ Department of Haematology and Bone Marrow Transplantation, Silesian Medical University, Katowice, Poland

${ }^{8}$ Institute of Haematology and Transfusion Medicine, Warsaw, Poland

${ }^{9}$ Maria Sklodowska-Curie National Research Institute of Oncology, Warsaw, Poland

${ }^{10}$ Maria Skłodowska-Curie National Research Institute of Oncology, Kraków, Poland

${ }^{11}$ Department of Haematology, Collegium Medicum, Jagiellonian University, Kraków, Poland

${ }^{12}$ Department of Pathology and Laboratory Diagnostics, Maria Skłodowska-Curie National Research Institute of Oncology, Warsaw, Poland

${ }^{13}$ Department of Haematology, Medical University, Łódź, Poland

${ }^{14}$ Department of Dermatology, Venereology and Allergology, Medical University of Gdańsk, Gdańsk, Poland

${ }^{15}$ Department of Paediatric Haematology and Oncology, Collegium Medicum, Nicolaus Copernicus University in Toruń,

Bydgoszcz, Poland

\section{Abstract}

The number of newly diagnosed haematological malignancies in Polish adults and children is about 9,000 a year, which constitutes about $5.5 \%$ of all malignancies in the country. Adult patients with haematological malignancies are diagnosed and treated in 42 institutions in Poland. The scientific and educational support for this activity is provided under the umbrella of the Polish Society of Haematologists and Transfusiologists (PTHiT, Polskie Towarzystwo Hematologów i Transfuzjologów), the Polish Adult Leukemia Group (PALG), the Polish Lymphoma Research Group (PLRG), the Polish Myeloma Study Group (PMSG), the Polish Myeloma Consortium (PMC), and consultants in haematology.

\footnotetext{
*Address for correspondence: Jan Styczyński, Department of Paediatric Haematology and Oncology, Collegium Medicum, Nicolaus Copernicus University in Toruń, Skłodowskiej-Curie 9, 85-094 Bydgoszcz, Poland, phone: +485258548 60, fax: +485258540 87, e-mail: jstyczynski@cm.umk.pl
}

PTHiT Copyright (C) 2021 The Polish Society of Haematologists and Transfusiologists, प्राय Insitute of Haematology and Transfusion Medicine. All rights reserved. 
The aim of this position paper is to present the current status and progress in therapy of haematological malignancies in Polish haematology adult centres, focusing on the activity of PALG, PLRG, and PMSG. The achievements of Polish haemato-oncology at the beginning of the third decade of the $21^{\text {st }}$ century are set out in this paper. Polish haemato-oncology today has an important international position based on contributions to the development of knowledge, international cooperation, and a high quality of patient care. In many instances, clinical trials run by Polish collaborative groups have influenced international standards. Polish haematologists have been the authors of treatment recommendations, and their research has indicated areas for further research.

Key words: Polish Society of Haematologists and Transfusiologists, Polish Adult Leukemia Group, Polish Lymphoma Research Group, Polish Myeloma Study Group

Acta Haematologica Polonica 2021; 52, 1: 4-17

\section{Introduction - haematology in Poland}

Adult patients with haematological malignancies are diagnosed and treated in 42 institutions in Poland. The scientific and educational support for this activity is provided under the umbrella of the Polish Society of Haematologists and Transfusiologists (PTHiT, Polskie Towarzystwo Hematologów i Transfuzjologów), the Polish Adult Leukemia Group (PALG), the Polish Lymphoma Research Group (PLRG), the Polish Myeloma Study Group (PMSG), and consultants in haematology.

The Polish Society of Haematology (PTH, Polskie Towarzystwo Hematologiczne) was created in 1949 by Prof. Tadeusz Tempka. From the first meeting of the Society in 1950 in Kraków, Prof. Tempka was its President up to 1972. From 1972 to 1976, Prof. Hugon Kowarzyk was the President. He changed the name of the society to the PTHiT in 1975. The next Presidents were: Prof. Józef Japa (1976-1987), Prof. Janusz Hansz (1987-1995), Prof. Wiesław W. Jędrzejczak (1995-2003), Prof. Andrzej Hellmann (2003-2011), Prof. Tadeusz Robak (2011-2019) and Prof. Iwona Hus (since 2019). The Society has biannual meetings. PTHiT meetings were held in Białystok 2001; Gdańsk 2003; Katowice/Wisła 2005; Warsaw 2007; Wrocław 2009; Lublin 2011; Poznań 2013; Szczecin 2015, Warsaw 2017, and Łódź in 2019. The $29^{\text {th }}$ Meeting will be held in Bydgoszcz in 2021.

The position of national consultant in haematology was held consecutively by Prof. Lech Konopka (1997-2001), Prof. Jerzy Hołowiecki (2001-2002), Prof. Wiesław Jędrzejczak (2002-2014), Prof. Dariusz Wołowiec (2014-2016), again Prof. Jędrzejczak (2016-2018), and Prof. Ewa Lech-Marańda (since 2018). The current team of regional consultants comprises: Lidia Usnarska-Zubkiewicz (woj. dolnośląskie), Małgorzata Całbecka (woj. kujawsko-pomorskie), Marek Hus (woj. lubelskie), Katarzyna Brzeźniakiewicz-Janus (woj. lubuskie), Piotr Smolewski (woj. łódzkie), Tomasz Sacha (woj. małopolskie), Bożena Katarzyna Budziszewska (woj. mazowieckie), Dariusz
Woszczyk (woj. opolskie), Mirosław Markiewicz (woj. podkarpackie), Jarosław Andrzej Piszcz (woj. podlaskie), Wojciech Homenda (woj. pomorskie), Małgorzata Wojciechowska (woj. warmińsko-mazurskie), Małgorzata Krawczyk-Kuliś (woj. śląskie), Marcin Pasiarski (woj. świętokrzyskie), Lidia Gil (woj. wielkopolskie), and Barbara Zdziarska (woj. zachodniopomorskie).

The Polish Adult Leukemia Group was created in 1975 and chaired by Prof. Jerzy Hołowiecki up to 2014, followed by Prof. Sebastian Giebel. The Polish Lymphoma Research Group was created in 2008 and chaired by Dr Janusz Meder followed by Prof. Sebastian Giebel. PALG and PLRG include a total of 36 haematology adult centres actively participating in scientific activity.

The aim of this position paper is to present the current status, achievements and progress in the therapy of haematological malignancies in Polish haematology adult centres, focusing on the activity of PALG, PLRG, and PMSG.

\section{Epidemiology of haematological malignancies in Poland}

\section{Morbidity}

According to the National Cancer Registry, the number of newly diagnosed malignancies in the Polish population in 2017 was 164,875 including 8,988 (5.45\%) haematological malignancies (Table I) [1]. However, it is worth noting that the National Cancer Registry does not include newly diagnosed patients with myelodysplastic syndromes (D46) or myeloproliferative neoplasms such as polycythemia vera (D45), primary myelofibrosis (D47.1), and essential thrombocythemia (D75.2). Data from the National Health Fund (NFZ, Narodowy Fundusz Zdrowia) from 2014 indicates there were 1,444 new patients with myelodysplastic syndromes and 3,382 patients with myeloproliferative neoplasms [2].

The National Cancer Registry provides the following general information regarding the epidemiology of the most frequent haematological malignancies [1]. 
Table I. Newly diagnosed haematological malignancies and morbidity rates in Poland in 2017 (no age limits) [1]

\begin{tabular}{|l|l|c|c|c|}
\hline ICD-10 & Malignancy & $\begin{array}{c}\text { Newly diagnosed } \\
(\mathbf{2 0 1 7})\end{array}$ & $\begin{array}{c}\text { Morbidity rate } \\
\text { morbidity ratio }\end{array}$ \\
\hline C00-D09 & All malignancies & $164,875(100 \%)$ & 429.11 & 323.50 \\
\hline C81 & Hodgkin's lymphoma & $753(0.46 \%)$ & 1.96 & 1.90 \\
\hline C82 & Follicular lymphoma & $442(0.27 \%)$ & 1.15 & 0.93 \\
C83 & Non-follicular lymphoma & $1,535(0.93 \%)$ & 4.00 & 3.11 \\
\hline C84 & Other specified types of T/NK-cell lymphoma & $244(0.15 \%)$ & 0.64 & 0.51 \\
\hline C85 & Other and unspecified types of non-Hodgkin's lymphoma & $848(0.51 \%)$ & 2.21 & 1.67 \\
\hline C88 & Malignant immunoproliferative diseases & $67(0.04 \%)$ & 0.17 & 0.13 \\
\hline C90 & Multiple myeloma and malignant plasma cell neoplasms & $1,600(0.97 \%)$ & 4.16 & 3.02 \\
\hline C91 & Lymphoid leukemia & $1,801(1.09 \%)$ & 4.69 & 3.78 \\
\hline C92 & Myeloid leukemia & $1,119(0.68 \%)$ & 2.91 & 2.28 \\
\hline C93 & Monocytic leukemia & $71(0.04 \%)$ & 0.18 & 0.13 \\
\hline C94 & Other leukemias of specified cell type & $375(0.23 \%)$ & 0.98 & 0.72 \\
\hline C95 & Leukemia of unspecified cell type & $57(0.03 \%)$ & 0.15 & 0.11 \\
\hline C96 & Other and unspecified malignant neoplasms of lymphoid, & $76(0.05 \%)$ & 0.20 & 0.16 \\
& haematopoietic and related tissue & $8,988(5.45 \%)$ & 23.40 & 18.45 \\
\hline
\end{tabular}

The morbidity rate is the frequency or proportion with which a disease appears in a population. Standardised morbidity ratio is the ratio between the observed number of new diagnoses in a study population and the number of new diagnoses that would be expected based on the age- and sex-specific rates in a standard population and the population size of the study population by the same age/sex groups (European population is assumed as standard population); ICD-10 - International Statistical Classification of Diseases and Health-Related Problems; NK - natural killers

\section{Leukemia}

Patients with leukemia comprise $2 \%$ of malignancies. The number of newly diagnosed patients with leukemia in 2017 was 3,423. There is an age-dependent increasing trend in the number of newly diagnosed patients. The risk of leukemia in children, adolescents and young adults (AYA) is $4 / 10^{5}$, and this risk steadily increases after the age of 50 .

\section{Myeloid leukemia}

Myeloid leukemia (acute and chronic, as reported in ICD-10) comprises $0.7 \%$ of malignancies. The number of newly diagnosed patients with myeloid leukemia in 2017 was 1,119, with $55 \%$ of diagnoses at age 55-79. Patients diagnosed with myeloid leukemia between 2003 and 2005 had a 1-year survival rate of $45.5 \%$ in males and $46.6 \%$ in females.

\section{Lymphoid leukemia}

Lymphoid leukemia (acute and chronic, as reported in ICD-10) comprises $1.1 \%$ of malignancies. The number of newly diagnosed patients with lymphoid leukemia in 2017 was 1,801. There are two peak incidence periods: childhood and old age. Patients diagnosed with myeloid leukemia between 2003 and 2005 had a 1-year survival rate of $74.7 \%$ in males and $77.3 \%$ in females.

\section{Multiple myeloma (MM)}

This comprises $1 \%$ of malignancies. The number of newly diagnosed patients with MM in 2017 was 1,600, with 75\% of diagnoses in those aged over 60 . The peak incidence is for people in their 70 s: $20 / 10^{5}$ in males and $15 / 10^{5}$ in females. Patients diagnosed with MM between 2003 and 2005 had a 1-year survival rate of $62.9 \%$ in males and $66.0 \%$ in females.

\section{Hodgkin's lymphoma (HL)}

This comprises $0.5 \%$ of malignancies. The number of newly diagnosed patients with $\mathrm{HL}$ in 2017 was 753 . More than $50 \%$ of new diagnoses in males, and $65 \%$ in females, are made between the ages of 15 and 40 . The peak incidences occur between 25-30 and after the age of 70. Patients diagnosed with HL between 2003 and 2005 had a 1-year survival rate of $89.2 \%$ in males and $91.5 \%$ in females.

\section{Non-Hodgkin's lymphoma (NHL)}

This comprises $2 \%$ of malignancies. The number of newly diagnosed patients with NHL in 2017 was 3,069. More than $70 \%$ of new NHL diagnoses are made after the age of $50 . \mathrm{NHL}$ comprises $7.5 \%$ in children, and $5 \%$ in age $20-44$. Patients diagnosed with NHL between 2003 and 2005 had a 1-year survival rate of $68.5 \%$ in males and $70.2 \%$ in females.

\section{Acute myeloid leukemia}

Treatment of newly diagnosed AML

Therapeutic management in AML depends on prognostic factors, particularly the patient's age and cytogenetic as 
well as molecular features [3]. Achievement of complete remission (CR) after induction treatment is a prerequisite for successful therapy and prolongation of overall survival (OS). In PALG studies, attempts have been made to modify the standard DA-60 induction protocol (daunorubicin [DNR] $60 \mathrm{mg} / \mathrm{m}^{2}$ for three consecutive days in combination with cytosine arabinoside [Ara-C] at a dose of 100-200 mg/ $/ \mathrm{m}^{2} /$ day for seven days) in order to improve the efficacy of induction treatment in AML patients eligible for intensive chemotherapy.

Two multicentre randomised trials conducted by PALG demonstrated that the addition of cladribine at a dose of $5 \mathrm{mg} / \mathrm{m}^{2} /$ day in a two-hour infusion for five consecutive days adhering to the DA induction (DAC protocol) had a beneficial impact in newly diagnosed $A M L$ patients $\leq 60$ years of age $[3,4]$. In the DAC arm, CR rate was significantly higher $(67.5 \%)$ and the occurrence of primary resistance to chemotherapy rarer (21\%) compared to standard DA-60 therapy (56\%; $p=0.01$ and 34\%; $p=0.004$, respectively). The addition of cladribine also exerted a significant effect on OS improvement (3-year OS, $45 \%$ vs. 33\%), particularly in patients $>50$ years, with high leukocytosis ( $>50 \mathrm{G} / \mathrm{L}$ ), and in the group with unfavourable karyotype [4]. A retrospective analysis showed that the DAC treatment was associated with improved $\mathrm{CR}$ and $\mathrm{OS}$ rates in the subgroup of patients with FLT3-ITD mutation [5]. In AML patients older than 60 years, DAC appeared to be superior in the subgroup aged 60-65 (CR rate: DAC 51\% vs. DA 29\%; $p=0.02$ ). What's more, patients with good and intermediate karyotypes benefited from the addition of cladribine also in terms of OS ( $p=0.02)$ [6]. No differences in haematological and non-haematological toxicity between the DA and DAC regimens in all trials were observed. In a prospective study, outcomes in 509 elderly patients with AML with different treatment approaches depending on Eastern Cooperative Oncology Group (ECOG) performance status and Charlson Comorbidity Index (CCl) were estimated [7].

\section{Treatment of refractory and relapsed AML}

A significant limitation of AML treatment is the impossibility of achieving CR with standard induction chemotherapy in $20-30 \%$ of patients. In more than half of the patients with $\mathrm{CR}$, leukemia relapse can occur within three years of the initial diagnosis.

The results of the multicentre PALG phase II clinical trials have indicated that cladribine and high-dose Ara-C combined with G-CSF (CLAG) and mitoxantrone (CLAG-M) is a highly efficient treatment for refractory and relapsed AML $[8,9]$. The results of the subsequent PALG phase II study showed that the CLAG-M protocol has high antileukemic activity and moderate toxicity in poor prognosis patients with primary drug-resistant AML or in those demonstrating early relapse $(1 \mathrm{CR}<6$ months) or relapse after stem cell transplantation [10]. Based on these promising results, in the next phase II trial CLAM (cladribine + Ara-C + mitoxantrone \pm G-CSF) was used as an early second induction on day 16 based on bone marrow blasts on day 14 in AML patients aged under 60 years who received DAC as first induction. The study results showed that CLAM used as early second induction might improve $\mathrm{CR} / \mathrm{CR}$ i rates for younger AML patients with poor early response to DAC induction, but this approach may be associated with higher mortality [11].

\section{Treatment of acute promyelocytic leukemia (APL)}

In Poland, patients with acute promyelocytic leukemia (APL) are treated in cooperation with the PETHEMA (Programa Español para el Tratamiento de las Hemopatías Malignas) group and according to current PETHEMA protocols. A retrospective analysis of a real-life Polish population showed that early death (ED) remains a major problem in APL, and that shortening the time between the initial contact with a healthcare professional and all-trans retinoic acid administration, as well as the use of appropriate supportive care, could improve the outcomes of an unselected APL population [12].

\section{Currently ongoing clinical trials}

The PALG-AML1/2016 study aims to compare the safety and efficacy of two commonly used induction (DAC vs. DA-90) and salvage (CLAG-M vs. FLAG-IDA) regimens in $A M L$. This trial is also the first international randomised trial regarding $A M L$ induction to prospectively evaluate the impact of measurable residual disease (MRD) on overall survival, using multi-modality testing (flow-cytometry, next-generation sequencing, and PCR) of serial samples. (ClinicalTrials.gov Identifier: NCT03257241). In the PALG-AML-1/2018 phase I/Ib trial, the safety and efficacy of a combination of CPX-351 with cladribine in elderly patients with relapsed/refractory acute myeloid leukemia is being analysed (EudraCT: 2020-002535-29).

\section{Chronic myeloid leukemia}

In monitoring the treatment results of chronic myeloid leukemia $(\mathrm{CML})$ with the use of tyrosine kinase inhibitors (TKIs), special attention is paid to appropriate follow-up with molecular methods, which should be performed in certified laboratories able to issue the results of real-time quantitative PCR (RQ-PCR) using the international scale (IS). Polish Molecular Laboratories have been organised in the National Network and have joined the European Leukemia Net and EUTOS projects dedicated to the standardisation of quantitative BCR-ABL1 analysis in patients with CML [13]. The National Molecular Reference Laboratory has been established in Kraków, and this has successfully conducted standardisation and certification procedure in 
16 Polish laboratories currently issuing results using the IS [14]. Poland was the first European country with registered imatinib generics in 2014. PALG has established a webpage-based registry to evaluate prospectively the efficacy and tolerability of imatinib generics in a large cohort of adult patients. The report after one year of follow-up of 726 patients (99 previously untreated and 627 patients switched from branded to generic imatinib) showed equal efficacy and tolerability of imatinib generics compared to the branded drug [15].

\section{Myeloproliferative neoplasms Ph-negative}

The discovery of mutations that finally confirmed the clonality of Ph-negative myeloproliferative neoplasms resulted in the development of molecular studies also in Polish research centres. This allowed for the characterisation of the Polish population in terms of the presence of new mutations [16], as well as the detection of new mutations in atypical exons of the JAK gene and the MPL gene. Also the subject of research interest was the relationship between the occurrence of complications and the diversified course of diseases depending on the changes in the genome.

In 2018, the results of studies on the evolution of the clinical picture of myeloproliferative neoplasms were published, showing no effect of allele burden on the occurrence of polycythemic transformation [17]. As a result of the cooperation of the centres of the Myeloproliferative Neoplasms Working Group, analysis of the incidence of secondary von Willebrand syndrome in myeloproliferative neoplasms has been published, where it has been shown that this haemostatic pathology is not limited to essential thrombocythemia [18]. In 2019, the preliminary results of a multicentre study of Polish patients treated with ruxolitinib due to myelofibrosis were presented.

\section{Myelodysplastic syndromes (MDS)}

In Poland, the standard of care of MDS patients adheres to the current ELN recommendations. In 2008, the MDS Working Group within PALG included 960 MDS patients into a retrospective Polish MDS Registry. Since 2009, 2,513 MDS, AML $<30 \%$ BM blasts and MDS/MPN patients have been registered prospectively. Cytogenetic results availability improved between 2009-2010 and 2018-2019 from $45 \%$ to $77 \%$. Serum ferritin (SF) had a significant impact on outcomes. Patients with higher than $1,000 \mathrm{ng} / \mathrm{mL}$ SF versus patients with $\mathrm{SF}<1,000 \mathrm{ng} / \mathrm{mL}$ had a median survival of 320 days versus 568 days ( $p=0.014$ ) [19]. Assuming that azacitidine (AZA) treated patients are at higher risk of serious infection, especially within the first three AZA cycles, between 2009 and 2016296 patients were retrospectively analysed. It was found that red blood cell transfusion dependency [odds ratio $(\mathrm{OR})=2.38$ ], neutropenia $<0.8 \times 10^{9} /$
$/ L(O R=3.03)$, platelet count $<50 \times 10^{9} / L(O R=2.63)$, albumin level $<35 \mathrm{~g} / \mathrm{L}(\mathrm{OR}=2.04)$ and ECOG performance status $\geq 2(O R=2.19)$ all had a significant impact on infectious risk. A subset of patients was selected with high risk of infection rate, $73 \%$ versus $25 \%$, and worse clinical outcome, 8 versus 29 months survival [20].

\section{Hypereosinophilic syndrome}

Hypereosinophilic syndrome (HES) is a group of rare disorders with a unique clinical picture and challenging treatment. Over the last 20 years, we have witnessed an eruption of molecular findings leading to improved understanding of HES pathogenesis. A small proportion of HES patients may have an abnormal T-cell population responsible for the overproduction of eosinophilopoietic cytokines. These patients are defined to have lymphocytic variant HES. Peripheral blood samples from 42 HES patients were studied for the presence of T-cell receptor rearrangement by PCR and aberrant T lymphocytes by flow cytometry. Clonal T-cell rearrangements were detected in 18 individuals (42.8\%) whereas an abnormal T-cell population was revealed only in three patients, with the conclusion that T-cell abnormalities are frequently found in HES [21]. Approximately $10 \%$ of HES patients present an interstitial deletion in chromosome $4 q 12$ leading to the expression of FIP1L1-PDGFR $\alpha$ (F/P) - an imatinib-sensitive gene fusion.

Within the Polish Hypereosinophilic Syndrome Study Group, 32 patients were identified as meeting HES criteria and expressing F/P. Male gender greatly predominated (94\%) and splenomegaly and pulmonary involvements were most frequently observed. Treatment with imatinib mesylate (IM) resulted in haematological and molecular CR in $100 \%$ of the studied patients. The response was rapid and durable. Imatinib at $100 \mathrm{mg}$ weekly was sufficient to maintain CR in long-term follow-up. The updated results after a median of 12 years on IM have confirmed its excellent efficacy and safety. None of the patients exhibited IM resistance or transformed into acute leukemia. Seven patients stopped IM after achieving long-term remission, and two of them remained in $\mathrm{CR}$ for more than seven years after $\mathrm{IM}$ discontinuation. IM re-initiation leads to second $\mathrm{CR}$ in nearly all patients $[22,23]$.

\section{Acute lymphoblastic leukemia (ALL)}

The treatment of ALL in adults has been based on BFM-like protocols in Poland for more than two decades. Since 1996, adult patients in Poland have been treated with a uniform PALG protocol, with treatment outcomes recorded in prospective studies. A randomised trial demonstrated that the use of granulocyte-colony stimulating factor enabled better adherence to chemotherapy and 
improved overall survival of ALL patients [24]. In a phase II study, the safety and efficacy of an originally-developed FLAM regimen (fludarabine, cytarabine, and mitoxantrone) was assessed for patients with relapsed/refractory ALL [25]. The PALG 4-2002 study showed that MRD level $\geq 0.1 \%$ of bone marrow cells after induction assessed by flow cytometry should be considered an independent risk factor for treatment decisions in adult ALL [26]. The combination of MRD status with conventional risk stratification system identified a subgroup of patients allocated to the SR group with MRD $\geq 0.1 \%$ after induction who had a risk of relapse of $71 \%$ at three years, versus $9 \%$ in the remaining subjects $(p=0.001)$ [26]. The prognostic value of MRD may be further increased when cytogenetic features are included in the model [27]. Consequently, flow cytometric MRD positive status, i.e. $\geq 0.1 \%$ after induction and $\geq 0.01 \%$ after consolidation, is considered an independent risk factor in the current ALL7 PALG protocol which was introduced in October 2018. Since L-asparaginase is one the core drugs in PALG protocols, recommendations were published on the use of L-asparaginase in ALL [28]. PALG is currently initiating a randomised, multicentre trial to compare obinutuzumab versus rituximab in newly diagnosed CD20-positive B-cell ALL. A Polish group led an international collaboration to establish recommendations regarding the role of allo-HCT in Ph-negative ALL [29].

\section{Chronic lymphocytic leukemia (CLL)}

Biology, prognostic factors and the treatment of CLL have been important targets of research for Polish haematologists in recent decades. Basic and pre-clinical studies performed in several Polish academic haematology departments have contributed to the current understanding of the molecular background and immunology of CLL [30]. However, the greatest achievement was the creation of a CLL clinical research programme within the PALG by Prof. Robak that was aimed at the active development of new therapies for CLL, mainly purine nucleoside analogue cladribine (2-CdA)-based combinations [31, 32]. Besides a number of early phase studies, this successful cooperation within PALG led to the setting up of four large prospective, multi-centre randomised phase III clinical trials (PALG CLL1-4) that included a total of 1,288 untreated CLL patients between 1995 and 2011. As a result, several active regimens such as $\mathrm{CC}$ (cladribine and cyclophosphamide) or RCC (rituximab, cladribine, and cyclophosphamide) have been recommended as up-front therapy of CLL by national guidelines and implemented into routine care in Poland. Furthermore, rare CLL complications have constituted another area of study where Polish observations have enabled better characterisation of epidemiology and clinical course of autoimmune conditions, and secondary neoplasms including Richter's syndrome [33].

\section{Follicular lymphoma}

The treatment of follicular lymphoma $(F L)$ in Poland has been under the supervision of the PLRG since 2008. Two randomised clinical trials (RCT) were conducted, PLRG1 and PLRG4. In the pre-rituximab era, treatment-naïve patients with indolent lymphomas, including $28 \%$ of patients with follicular lymphoma, were enrolled into phase III PLRG1 RCT, comparing the efficacy of three protocols: cladribine monotherapy, CC (cladribine and cyclophosphamide), and CVP (cyclophosphamide, vincristine, and prednisone). Protocols containing cladribine yielded significantly better overall responses and complete remission rates and progression-free survival (PFS) times, but not OS [34]. PLRG4, phase III RCT, conducted already in the rituximab era, compared two induction chemoimmunotherapy protocols, R-CVP and $\mathrm{R}-\mathrm{CHOP}$, followed by rituximab maintenance, for indolent lymphomas [35]. Patients with FL constituted $42 \%$, while patients with marginal zone lymphoma comprised 38\%, among 250 enrolled patients. The frequency of response did not differ between the study arms and the time-to-event endpoints i.e. event-free survival (EFS), PFS and OS, were similar. The only indolent lymphoma with a significantly worse outcome was small lymphocytic lymphoma. Five-year EFS for the whole group reached $61 \%$ and $56 \%$ in the $\mathrm{R}-\mathrm{CHOP}$ and the R-CVP arms, respectively. The occurrence of early progression of FL (POD24) was similarly frequent in both arms (13.7 vs. $16.7 \%, p>0.05)$. Grade III/IV adverse events occurred more frequently in the R-CHOP arm compared to the R-CVP arm (55.1 vs. 18.2\%). Based on the results of this trial, the R-CVP regimen is preferentially used in PLRG centres for follicular lymphoma patients requiring therapy. In earlier years, PLRG centres participated also in studies involving patients with relapsed/refractory indolent lymphomas, including FL, treated either with four weekly doses of rituximab [36] or radioimmunotherapy [37].

\section{Hodgkin's lymphoma (HL)}

A new era in the treatment of Hodgkin's lymphoma $(\mathrm{HL})$ in Poland started in the past decade with the use of positron emission tomography (PET/CT) for staging [38], interim and final response assessment. Centres allied to the PLRG took part in the validation study of the Deauville Scale, conducted a prospective trial assessing the role of very early interim PET (after one cycle) [39], and developed a new chemotherapy regimen composed of bendamustine, gemcitabine and dexamethasone (BGD) [40] for relapsed/ /refractory $\mathrm{HL}$. BGD is now being assessed in a prospective study (BURGUND, EudraCT: 2017-001966-97) in patients with progressive disease after first line treatment. The PLRG, together with international partners, has proposed a personalised PET-adapted treatment of early non-bulky $\mathrm{HL}$ (eHL) using an innovative risk and response-adapted 
strategy. The RAFTING study (EudraCT: 2020-002382-33) aims to assess the efficacy of standard treatment followed by nivolumab in high risk eHL patients defined by positive interim PET (iPET) and/or by high $\left(>84 \mathrm{~cm}^{3}\right)$ initial metabolic tumour volume (MTV) and chemotherapy alone in low risk eHL (defined by both a low MTV and a negative iPET) and the rate of $\mathrm{HL}$ relapses in low-risk patients that could be salvaged with delayed radiotherapy and nivolumab maintenance.

\section{Diffuse large B-cell lymphoma}

Diffuse large B-cell lymphoma (DLBCL) is the most common aggressive $B$ cell lymphoma subtype, and prognosis depends on the efficacy of first line therapy. Polish Lymphoma Research Group (PLRG) centres have participated in the most important multicentre studies establishing R-CHOP as the present standard of care (Prof. Jan Walewski), and protocols investigating the potential role of Bruton tyrosine kinase inhibitors and immunomodulating agents (Prof. Wojciech Jurczak). PLRG, in a national multicentre study, confirmed the role of R-CHOP in high risk DLBCL patients [41]. Cardiovascular toxicity of doxorubicin was addressed in several studies, confirming premature cardiovascular mortality [42], investigating the role of arterial hypertension [43], and the feasibility of cardioprotection [44]. Pre-existing diabetes was identified as an independent risk factor of adverse prognosis [45]. In a multicentre approach, PLRG investigated the efficacy of the PREBEN regimen (pixantrone, rituximab, etoposide, and bendamustine) in relapsing refractory cases [46].

\section{Hairy cell leukemia}

Hairy cell leukemia (HCL), a chronic lymphoproliferative disorder, responds well to treatment, and one course of cladribine (2-chlorodeoxyadenosine, 2-CdA) usually induces a durable CR. However, there are several administration schedules of this drug and no superiority has been shown of one schedule over the others. Robak et al. [47] demonstrated CR obtained in $75 \%$ of patients after 5 -day intravenous infusions of $2-\mathrm{CdA}$, and in $76 \%$ after 7 -day courses. Intermittent 2-hour infusions and continuous 24-hour infusions yielded CR in $82.6 \%$ and $66.7 \%$ of patients respectively. In another study, Robak et al. [48] compared the efficacy and toxicity of a standard 5-day 2-CdA protocol with a schedule of six weekly 2-CdA infusions. Neither the efficacy nor the toxicity profile was significantly different between the groups. In particular, CR was obtained in 76\% of patients in the group of daily 2-CdA administration and in $72 \%$ in the weekly administration group. Both PFS and OS were similar in both groups. 2-CdA at $0.12 \mathrm{mg} / \mathrm{kg}$ in 2-hour i.v. infusion for five days; or alternatively 2-CdA at $0.12 \mathrm{mg} / \mathrm{kg}$ in 2-hour intravenous infusion once a week for six weeks are currently considered in Poland as the standard first line treatment for classical HCL.

\section{Peripheral T cell lymphomas}

Peripheral T-cell lymphomas (PTCL) are a heterogenous group of rare diseases that are challenging to treat. Patients with PTCL are treated with the CHOP or CHOP-like regimens used as an induction chemotherapy followed by autologous haematopoietic stem cell transplantation (auto-HCT) as a consolidation of first response. To expand the published experience, Czyż et al. [49] conducted a multicentre, retrospective review of 65 patients with PTCL who underwent auto-HCT as a consolidation of first response achieved with either initial induction chemotherapy or salvage chemotherapy. With the median follow-up of 53 months (range 7-157 months), the 5-year OS and PFS for all patients were $61.5 \%$ and $59.4 \%$, respectively. Bone marrow involvement at diagnosis and less than partial remission after induction chemotherapy were factors independently predictive for OS and PFS. Maciejka-Kłembowska et al. published a data report from the Polish Paediatric Leukemia/Lymphoma Study Group on clinical features and treatment outcomes of PTCL in 10 children [50]. Different regimens, including CHOP and protocols for lymphoblastic lymphoma, were used. The 5-year OS and event-free survival rates were $63.9 \%$ and $81 \%$, respectively. Three children underwent allogeneic HCT, and all of them remain alive and in complete remission.

\section{Mantle cell lymphoma}

The mantle cell lymphoma (MCL) treatment paradigm has evolved over recent years in Poland. The National Research Institute of Oncology joined the European Mantle Cell Lymphoma Network (EMCLN) and co-performed two landmark academic clinical trials for untreated MCL patients. In the 'younger' trial, a comparison of R-CHOP (rituximab, cyclophosphamide, doxorubicin, vincristine, and prednisone) and autologous haematopoietic cell transplantation (auto-HCT) consolidation versus alternating cycles of R-CHOP and R-DHAP (rituximab, cisplatin, cytarabine, and dexamethasone) with auto-HCT showed improved time-to-treatment failure [median 3.9 vs. 9.1 years and $40 \%$ vs. $65 \%$ at 5 year ( $p=0.038)$ ] for the treatment containing cytarabine [51].

The 'elderly' trial demonstrated that the recommended treatment in elderly patients is R-CHOP and rituximab maintenance $[52,53]$. Median overall survival (OS) after R-CHOP was 6.4 versus 3.9 years after R-FC (rituximab, fludarabine, and cyclophosphamide) ( $p=0.0054)$. Patients responding to R-CHOP had median progression-free survival (PFS) and OS of 5.4 and 9.8 years when randomised to rituximab versus $1.9(p<0.0001)$ and 7.1 years $(p=0.0026)$ when randomised to interferon maintenance. Based on the 
results of this study, rituximab maintenance after immunochemotherapy treatment became the standard procedure in elderly patients. The Polish Lymphoma Research Group (PLRG), as the EMCLN sponsor's delegate in Poland, is currently conducting two subsequent first line trials: TRIANGLE for younger and MCL-R2 for elderly patients.

\section{Burkitt's lymphoma}

A major improvement in the outcomes of adult Burkitt's lymphoma patients was achieved in Poland after implementing intensive chemotherapy CODOX-M/IVAC within the UKLG LY06 study [54]. Long-term survival increased from the previous less than $20 \%$ to close to $70 \%$. Toxicity of treatment was substantial, with the rate of treatmentrelated death approaching 10\%. Efficacy was further improved with the introduction of the GMALL-B-ALL/ /NHL-2002 protocol of short intensive chemotherapy combined with rituximab including high-dose methotrexate, cytarabine, and triple intrathecal therapy [55]. This largest prospective multicentre trial for adult patients with Burkitt's lymphoma/leukemia involved 363 patients aged 16 to 85 from 98 European centres including the Oncology Institute in Warsaw. The rate of complete remission was $88 \%$, 5-year survival was $80 \%$, and 5-year progression-free survival was $71 \%$. There was no lethal toxicity. Given the high cure rates across a range of prognostic groups including age, IPI, and feasibility of immunochemotherapy in elderly patients, the GMALL-B-ALL/NHL-2002 protocol is now preferentially used in Poland.

\section{Cutaneous lymphomas}

The diagnosis and treatment of cutaneous lymphomas remains a major challenge [56]. Epigenetic dysregulation seems to play an important role in the development and progression of Sézary syndrome (SS). The TMEM244 gene is ectopically expressed in SS patients, SS-derived cell lines, and, to a lesser extent, in MF. TMEM244 expression is negatively correlated with the methylation level of its promoter. TMEM244 expression can be activated in vitro by the CRISPR-dCas9-induced specific demethylation of TMEM244 promoter region. Since both TMEM244 expression and its promoter demethylation can be potentially used as markers in SS and some other T-cell lymphomas [57], STAT5 but also STAT6 and to a lesser extent STAT3 seems to be constitutively activated in Cutaneous T-cell lymphomas (CTCL). Downregulation of STAT5b protein in advanced-stage CTCL appears to contribute to its pathogenesis. STATs seem to be a promising target for new effective therapeutic agents in CTCL [58]. WP1220 is a synthetic compound that potently inhibits p-STAT3 and the growth of CTCL cell lines. Topical treatment of index skin lesions in stage I-III MF have revealed safety and some efficacy in MF in the Phase $1 \mathrm{~b}$ study performed at the Medical University of Gdańsk [59].

\section{Multiple myeloma}

The Polish Myeloma Study Group (PMSG) was established by Prof. Anna Dmoszyńska in cooperation with Prof. Maria Kraj in 2005. One of the original clinical protocols was the evaluation of the efficacy and safety of multiple myeloma (MM) patient therapy with the CTD regimen (cyclophosphamide, thalidomide, and dexamethasone) based on a low dose of thalidomide $(100 \mathrm{mg} / \mathrm{d})$ [60]. Other clinical and multicentre studies of the PMSG were focused on therapy with lenalidomide, pomalidomide and bortezomib as well as the identification of novel cytogenetic prognostic factors [61-66].

The most significant change in the field of multiple myeloma in Poland in recent years was the launch of several prospective clinical trials initiated by Polish investigators. On the one hand this provided the opportunity to play a significant role in the development of new treatment strategies worldwide, and on the other hand it provided access to non-reimbursed drugs to Polish patients. PMC006 (ATLAS), a study that the Polish Myeloma Consortium launched in 2017, was the first non-commercial investigator-initiated clinical study in Poland; it completed the recruitment of its planned 160 patients in September 2020. This study assessed two different methods of maintenance after auto-PBSCT: R versus KRD.

There are three other important studies ongoing: the PMC007 (OBI1), which assesses the efficacy of obinutuzumab in patients with refractory or recurrent Waldenstroem macroglobulinemia; the PMC008 (PREDATOR), where daratumumab is used to treat patients with biochemical relapse of myeloma; and the PMC010 (COBRA), which assesses the effectiveness of KRD versus RVD in patients with newly diagnosed multiple myeloma. The Polish Myeloma Study Group and the Polish Myeloma Consortium are also active in the development of the MM Registry. Therefore, the prospective observational study PMCO09 (POMOST) was launched. In this trial, the treatment conditions and epidemiology of myeloma in Poland are prospectively assessed on a population of 1,500 patients. PMG and PMC also took part, together with the Łazarski University and the National Health Fund, in a pilot project to analyse the epidemiology and therapy of myeloma based on the sources of the NFZ [67]. PMSG regularly publishes recommendations for the diagnosis and treatment of MM. Several retrospective nationwide or international studies have been performed under the auspices of PMSG, including MM patients with CNS involvement [68], primary and secondary plasma cell leukemia $[69,70]$, primary refractory disease [71], t(14;16) [72], and biclonal MM [73]. As a result, it has been shown that the outcomes of advanced stage MM 
patients aged 21-40 are comparable to those of patients aged 41-60 [74].

\section{Autologous haematopoietic cell transplantation}

In 2019, 1,162 auto-HCTs (306 per 10 million inhabitants) were performed in Poland. Throughout the past decade, work has been underway aimed at the introduction and optimisation of a haematopoietic stem cell chemo-mobilisation protocol with the use of intermediate-dose cytarabine (ID-Ara-C) which is currently commonly used in Polish centres. ID-Ara-C refers to: cytarabine as a i.v. infusion at a dose of $0.4 \mathrm{~g} / \mathrm{m}^{2}$ twice daily on days +1 and +2 (total dose, $1.6 \mathrm{~g} /$ $/ \mathrm{m}^{2}$ ), with $10 \mu \mathrm{g} / \mathrm{kg}$ filgrastim started on day +5 . In a pilot report, its efficacy was shown when given as a second-line salvage mobilisation regimen. In a subsequent retrospective analysis, the greater benefit of ID-Ara-C compared to $4 \mathrm{~g} / \mathrm{m}^{2}$ cyclophosphamide as first-line mobilisation in patients with myeloma and lymphoma was demonstrated [75]. In a multicentre analysis from the PLRG, the superior efficacy of ID-Ara-C over DHAP plus G-CSF regimen in lymphoma patients was noted [76]. Finally, in a randomised trial, ID-Ara-C was shown to be superior to G-CSF alone for myeloma patients in terms of a greater proportion of patients achieving a CD34 ${ }^{+}$cell yield sufficient for tandem auto-HCT (98\% vs. $70 \%$ ), a higher median number of collected $\mathrm{CD} 4^{+}$cells (20.2 vs. $5.9 \times 10^{6}$ cells $/ \mathrm{kg}$ ), and faster haematopoietic recovery after auto-HCT [77].

\section{Allogeneic haematopoietic cell transplantation}

Six hundred and eighty-six allogeneic hematopoietic stem cell transplantations (allo-HCT) were performed in Poland in 2019 in 17 centres (12 adult and five paediatric). They included 185 transplantations from family members, 423 from unrelated people, and 78 from haploidentical donors. Since 2013, local Polish donors have predominated among unrelated donors (63\% in 2019). The Polish unrelated donor registry is one of the biggest in the world, accounting for more than 1.7 million volunteers. The most frequent indication for allo-HCT was acute myeloid leukemia (32\% of procedures from family, 36\% from unrelated, and $49 \%$ from haploidentical), followed by acute lymphoblastic leukemia (21\% from family and $20 \%$ from unrelated). Poland has been a very active member of the European Society for Blood and Marrow Transplantation (EBMT). In particular, two Polish investigators have been elected chairs of working parties and members of the EBMT's Scientific Council: Prof. Jan Styczyński (Infectious Diseases Working Party, 2016-2020) and Prof. Grzegorz Basak (Transplant Complications Working Party, 2017-2021). In addition, Prof. Sebastian Giebel since 2006 has been ALL subcommittee chair and secretary of the Acute Leukemia Working Party. Polish authors have substantially contributed to understanding the role of NK cell alloreactivity after allo-HCT [78], genetic polymorphisms contributing to GVHD [79], the role of pharmaco-economics [80], and the management of post-transplant lymphoproliferative disease (PTLD) [81], as well as having developed a number of international recommendations including treatment and outcome of viral infections following allo-HCT [82] and GVHD [83].

\section{Infectious complications}

Infectious complications constitute the major cause of morbidity and mortality in haematology and transplant patients. Cooperation between the Infection Disease Study Group of PALG with the Polish paediatric group PSPOH and the Infectious Diseases Working Party of EBMT has resulted in a number of publications. Polish epidemiological analysis on stem cell transplant recipients performed by PALG and PTHIT together with the Polish Society of Paediatric Oncology and Haematology (PTOHD, PSPOH) in a nationwide study revealed a high incidence of bacterial infections in children compared to adults ( $36 \%$ vs. $27.6 \% ; p<0.0001$ ), although with a substantial rate of Gram-negative bacteria in adults. Fungal infections were seen also more often in children (25.3\% vs. $6.3 \%$; $p<0.0001)$, as well as viral infections (88.0\% vs. $74.9 \% ; p<0.0001)$. Infection-related mortality was lower in children than in adults ( $7.8 \%$ vs. $18.4 \%$; $p<0.0001$ ) [84]. Sub-analysis of MM patients confirmed the importance of multidrug bacterial infections (37.5\% of Gram-negative; $54 \%$ of Gram-positive) during neutropenia after HCT, influencing mortality [85]. Important data regarding mucormycosis in haematology and transplant settings was published recently, based on 10-year observations. Analysis revealed high mortality (82\%) in patients undergoing allo-HCT, despite targeted therapy [86]. The treatment of infectious complications in haematology/transplant patients in Poland is based on systematically updated national recommendations. Recent guidance concerns vaccination in adult patients with haematological malignancies and after stem cell transplantation [87-89], the management of invasive fungal infections [90], the management of CMV infections after allo-HCT [91], and the management of infections after CAR T therapy [92].

\section{Haematopathology}

The National Histopathological Lymphoma Registry project (NHLR) was implemented in Poland in 2014 by haematopathologists from 24 pathology departments in accordance with the 2008 WHO Classification of Tumours of Haematopoietic and Lymphatic Tissues. DLBCL (32.9\%; 2,587), CLL/ /SLL (31.84\%; 2,504), HL (13.37; 1,567), PCM (13.32\%, 1,561) and MCL (9.04\%; 711) were the most frequent 
in a group of 11,718 tested patients. Major differences between NHLR and European and American data on lymphoma subtypes included a higher incidence of DLBCL, and lower incidences of FL and MALT [93]. The next study, based on 2000-2014 data from the Polish National Cancer Registry, confirmed a lower FL incidence rate in Poland compared to other European countries. FL was ranked fourth in incidence (CR $0.72 / 10^{5}$, SR $0.87 / 10^{5}$ ) among all reported mature B-cell non-Hodgkin lymphomas, after CLL/ /SLL (CR 3.62/10 ${ }^{5}$, SR 4.99/10 ${ }^{5}$ ), PCM (CR 3.78/10 5 , SR $4.97 / 10^{5}$ ) and DLBCL, NOS (CR 2.13/10 ${ }^{5}$, SR 2.65/10 ${ }^{5}$ ) [94]. A scheme of comprehensive haematopathological diagnostics of aggressive B-cell lymphomas based on morphology, immune profile and evaluation of MYC, BCL2, and $B C L 6$ gene statuses was proposed, and this was introduced in Poland after the publication of revised WHO classifications in 2017 [95].

\section{Molecular diagnostics}

During the last ten years, progress has been made in the molecular diagnostics of haematological malignancies in Poland in terms of the spectrum of techniques used, as well as its standardisation. In 2010, the standardisation of $B C R-A B L 1$ measurement by RQ-PCR in CML patients was carried out in eight laboratories in cooperation with the ELN [14]. The results of the BCR-ABL1 KD mutation analysis in imatinib-resistant patients were also published [96]. The RQ-PCR technique was improved by modification of the e13a2 and e14a2 transcript measurement in 2019 [97]. Similar progress has been made in the Ph-negative MPN. In 2015, the first results of the molecular characteristics of Polish patients were published [16]. The quality of JAK2 V617F quantification was assessed in an international study [98]. A comparison of qPCR and ddPCR sensitivity in the quantification of the JAK2 V617F mutation allele burden was performed in 2019 [99]. Further progress was made thanks to the introduction of GEP and NGS to myeloid malignancies diagnostics and MRD assessment [100-102]. A development has also been made in the CLL thanks to the cooperation with ERIC (European Research Initiative on CLL) and the creation of a reference laboratories network in Poland.

\section{Summary}

Polish haemato-oncology in the 2020s has an important international position based on many contributions to the development of knowledge, cooperation, and a high quality of patient care. In many instances, clinical trials run by Polish collaborative groups have influenced international standards. Polish haematologists have been the authors of many treatment recommendations, and their research has suggested areas for further research.

\section{Authors' contributions}

SG, JS, LG - design of study. All authors - collection of data and manuscript writing, critical revision and approval.

\section{Conflict of interest}

None.

\section{Financial support \\ None.}

\section{Ethics}

The work described in this article has been carried out in accordance with The Code of Ethics of the World Medical Association (Declaration of Helsinki) for experiments involving humans; EU Directive 2010/63/EU for animal experiments; Uniform requirements for manuscripts submitted to biomedical journals.

\section{References}

1. Wojciechowska U, Didkowska J. Zachorowania i zgony na nowotwory złośliwew Polsce. Krajowy Rejestr Nowotworów, Narodowy Instytut Onkologii im. Marii Skłodowskiej-Curie - Państwowy Instytut Badawczy. http://onkologia.org.pl/raporty/ (October 20, 2020).

2. Budziszewska BK, Więckowska B, Lech-Marańda E, et al. Zachorowalność i chorobowość na nowotwory układu krwiotwórczego w Polsce (2009-2015) określone na podstawie analizy danych Narodowego Funduszu Zdrowia wykorzystanych w projekcie „Mapy potrzeb zdrowotnych - baza analiz systemowych i wdrożeniowych”. Hematologia. 2017; 8(2): 89-104, doi: 10.5603/hem.2017.0013.

3. Holowiecki J, Grosicki S, Robak T, et al. Polish Adult Leukemia Group (PALG). Addition of cladribine to daunorubicin and cytarabine increases complete remission rate after a single course of induction treatment in acute myeloid leukemia. Multicenter, phase III study. Leukemia. 2004; 18(5): 989-997, doi: 10.1038/sj.leu.2403336, indexed in Pubmed: 14999298.

4. Holowiecki J, Grosicki S, Giebel S, et al. Cladribine, but not fludarabine, added to daunorubicin and cytarabine during induction prolongs survival of patients with acute myeloid leukemia: a multicenter, randomized phase III study. J Clin Oncol. 2012; 30(20): 2441-2448, doi: 10.1200/JC0.2011.37.1286, indexed in Pubmed: 22508825.

5. Libura M, Giebel S, Piatkowska-Jakubas B, et al. Cladribine added to daunorubicin-cytarabine induction prolongs survival of FLT3-ITD+ normal karyotype AML patients. Blood. 2016; 127(3): 360-362, doi: 10.1182/blood-2015-08-662130, indexed in Pubmed: 26567156.

6. Pluta A, Robak T, Wrzesien-Kus A, et al. Addition of cladribine to the standard induction treatment improves outcomes in a subset of elderly acute myeloid leukemia patients. Results of a randomized Polish Adult Leukemia Group (PALG) phase II trial. Am J Hematol. 2017; 92(4): 359-366, doi: 10.1002/ajh.24654, indexed in Pubmed: 28103640.

7. Budziszewska BK, Pluta A, Sulek K, et al. Treatment of elderly patients with acute myeloid leukemia adjusted for performance status and presence of comorbidities: a Polish Adult Leukemia Group study. Leuk Lymphoma. 2015; 56(8): 2331-2338, doi: 10.3109/10428194.2014.985672, indexed in Pubmed: 25393675.

8. Wrzesień-Kuś A, Robak T, Lech-Marańda E, et al. Polish Adult Leukemia Group. A multicenter, open, non-comparative, phase II study of 
the combination of cladribine (2-chlorodeoxyadenosine), cytarabine, and G-CSF as induction therapy in refractory acute myeloid leukemia - a report of the Polish Adult Leukemia Group (PALG). Eur J Haematol. 2003; 71(3): 155-162, doi: 10.1034/j.1600-0609.2003.00122.x, indexed in Pubmed: 12930315.

9. Wrzesień-Kuś A, Robak T, Wierzbowska A, et al. Polish Adult Leukemia Group. A multicenter, open, noncomparative, phase II study of the combination of cladribine (2-chlorodeoxyadenosine), cytarabine, granulocyte colony-stimulating factor and mitoxantrone as induction therapy in refractory acute myeloid leukemia: a report of the Polish Adult Leukemia Group. Ann Hematol. 2005; 84(9): 557-564, doi: 10.1007/s00277-005-1046-0, indexed in Pubmed: 15856358.

10. Wierzbowska A, Robak T, Pluta A, et al. Polish Adult Leukemia Group. Cladribine combined with high doses of arabinoside cytosine, mitoxantrone, and G-CSF (CLAG-M) is a highly effective salvage regimen in patients with refractory and relapsed acute myeloid leukemia of the poor risk: a final report of the Polish Adult Leukemia Group. Eur J Haematol. 2008; 80(2): 115-126, doi: 10.1111/j.1600-0609.2007.00988.x, indexed in Pubmed: 18076637.

11. Pluta A, Robak T, Brzozowski K, et al. Early induction intensification with cladribine, cytarabine, and mitoxantrone (CLAM) in AML patients treated with the DAC induction regimen: a prospective, non-randomized, phase II study of the Polish Adult Leukemia Group (PALG). Leuk Lymphoma. 2020; 61(3): 588-603, doi: 10.1080/10428194.2019.1678151, indexed in Pubmed: 31661339.

12. Sobas M, Czyż A, Montesinos P, et al. Outcome of a real-life population of patients with acute promyelocytic leukemia treated according to the PETHEMA guidelines: the Polish Adult Leukemia Group (PALG) Experience. Clin Lymphoma Myeloma Leuk. 2020; 20(2): 105-113, doi: 10.1016/j.clml.2019.09.616, indexed in Pubmed: 31874794.

13. Cross NCP, White HE, Colomer D, et al. Laboratory recommendations for scoring deep molecular responses following treatment for chronic myeloid leukemia. Leukemia. 2015; 29(5): 999-1003, doi: 10.1038/ /leu.2015.29, indexed in Pubmed: 25652737.

14. Sacha T, Zawada M, Czekalska S, et al. [Standardization of quantitative detection of BCR-ABL gene expression by RQ-PCR in patients with chronic myeloid leukemia in cooperation with European Leukemia Net] [in Polish]. Przegl Lek. 2010; 67(7): 454-459, indexed in Pubmed: 21387754.

15. Sacha T, Góra-Tybor J, Szarejko M, et al. A multicenter prospective study on efficacy and safety of imatinib generics: a report from Polish Adult Leukemia Group imatinib generics registry. Am J Hematol. 2017; 92(7): E125-E128, doi: 10.1002/ajh.24748, indexed in Pubmed: 28376561.

16. Wojtaszewska M, Iwoła M, Lewandowski K. Frequency and molecular characteristics of calreticulin gene (CALR) mutations in patients with JAK2 -negative myeloproliferative neoplasms. Acta Haematol. 2015; 133(2): 193-198, doi: 10.1159/000366263, indexed in Pubmed: 25323779.

17. Sobieralski P, Leszczyńska A, Bieniaszewska M. Late polycythemic transformation in JAK2-mutated essential thrombocythemia patientscharacteristics along with a validation of 2016 WHO criteria. Eur J Haematol. 2019; 103(6): 558-563, doi: 10.1111/ejh.13320, indexed in Pubmed: 31449697.

18. Mital A, Prejzner W, Świątkowska-Stodulska R, et al. Factors predisposing to acquired von Willebrand syndrome during the course of polycythemia vera - retrospective analysis of 142 consecutive cases. Thromb Res. 2015; 136(4): 754-757, doi: 10.1016/j. thromres.2015.07.029, indexed in Pubmed: 26269222.

19. Waszczuk-Gajda A, Mądry K, Machowicz R, et al. Red blood cell transfusion dependency and hyperferritinemia are associated with im- paired survival in patients diagnosed with myelodysplasticsyndromes: results from the First Polish MDS-PALG Registry. Adv Clin Exp Med. 2016; 25(4): 633-641, doi: 10.17219/acem/62397, indexed in Pubmed: 27629836.

20. Mądry K, Lis K, Biecek $\mathrm{P}$, et al. Predictive model for infection risk in myelodysplastic syndromes, acute myeloid leukemia, and chronic myelomonocytic leukemia patients treated with azacitidine; azacitidine infection risk model: the Polish Adult Leukemia Group Study. Clin Lymphoma Myeloma Leuk. 2019; 19(5): 264-274.e4, doi: 10.1016/j. clml.2019.01.002, indexed in Pubmed: 30898482.

21. Helbig G, Wieczorkiewicz A, Dziaczkowska-Suszek J, et al. T-cell abnormalities are present at high frequencies in patients with hypereosinophilic syndrome. Haematologica. 2009; 94(9): 1236-1241, doi 10.3324/haematol.2008.005447, indexed in Pubmed: 19734416.

22. Helbig G, Stella-Hołowiecka B, Majewski M, et al. A single weekly dose of imatinib is sufficient to induce and maintain remission of chronic eosinophilic leukaemia in FIP1L1-PDGFRA-expressing patients. Br J Haematol. 2008; 141(2): 200-204, doi: 10.1111/j.1365 2141.2008.07033.x, indexed in Pubmed: 18307562.

23. Helbig G, Lewandowski $K$, Świderska A, et al. Exquisite response to imatinib mesylate in FIP1L1-PDGFRA-mutated hypereosinophilic syndrome: a 12-year experience of the Polish Hypereosinophilic Syndrome Study Group. Pol Arch Intern Med. 2020; 130(3): 255-257, doi: 10.20452/pamw.15224, indexed in Pubmed: 32125294.

24. Giebel S, Holowiecki J, Krawczyk-Kulis M, et al. Impact of granulocyte colony stimulating factor administered during induction and consolidation of adults with acute lymphoblastic leukemia on survival: long-term follow-up of the Polish adult leukemia group 4-96 study. Leuk Lymphoma. 2009; 50(6): 1050-1053, doi: 10.1080/10428190902919176, indexed in Pubmed: 19455463.

25. Giebel S, Krawczyk-Kulis M, Adamczyk-Cioch M, et al. Polish Adult Leukemia Group. Fludarabine, cytarabine, and mitoxantrone (FLAM) for the treatment of relapsed and refractory adult acute lymphoblastic leukemia. A phase study by the Polish Adult Leukemia Group (PALG). Ann Hematol. 2006; 85(10): 717-722, doi: 10.1007/s00277-0060121-5, indexed in Pubmed: 16832677.

26. Holowiecki J, Krawczyk-Kulis M, Giebel S, et al. Status of minimal residual disease after induction predicts outcome in both standard and high-risk Ph-negative adult acute lymphoblastic leukaemia. The Polish Adult Leukemia Group ALL 4-2002 MRD Study. Br J Haematol. 2008; 142(2): 227-237, doi: 10.1111/j.1365-2141.2008.07185.x, indexed in Pubmed: 18492099.

27. Giebel S, Krawczyk-Kulis M, Kyrcz-Krzemien S, et al. Could cytogenetics and minimal residual disease replace conventional risk criteria in adults with Ph-negative acute lymphoblastic leukaemia? Br J Haematol. 2009; 144(6): 970-972, doi: 10.1111/j.13652141.2008.07540.x, indexed in Pubmed: 19120362.

28. Piatkowska-Jakubas B, Krawczyk-Kuliś M, Giebel S, et al. Polish Adult Leukemia Group. Use of L-asparaginase in acute lymphoblastic leukemia: recommendations of the Polish Adult Leukemia Group. Pol Arch Med Wewn. 2008; 118(11): 664-669, indexed in Pubmed: 19140571.

29. Giebel S, Marks DI, Boissel N, et al. Hematopoietic stem cell transplantation for adults with Philadelphia chromosome-negative acute lymphoblastic leukemia in first remission: a position statement of the European Working Group for Adult Acute Lymphoblastic Leukemia (EWALL) and the Acute Leukemia Working Party of the European Society for Blood and Marrow Transplantation (EBMT). Bone Marrow Transplant. 2019; 54(6): 798-809, doi: 10.1038/s41409-018-0373-4, indexed in Pubmed: 30385870. 
30. Giannopoulos K, Mertens D, Bühler A, et al. The candidate immunotherapeutical target, the receptor for hyaluronic acid-mediated motility, is associated with proliferation and shows prognostic value in B-cell chronic lymphocytic leukemia. Leukemia. 2009; 23(3): 519-527, doi: 10.1038/leu.2008.338, indexed in Pubmed: 19092852.

31. Robak T, Jamroziak K, Gora-Tybor J, et al. Comparison of cladribine plus cyclophosphamide with fludarabine plus cyclophosphamide as first-line therapy for chronic lymphocytic leukemia: a phase III randomized study by the Polish Adult Leukemia Group (PALG-CLL3 Study). J Clin Oncol. 2010; 28(11): 1863-1869, doi: 10.1200/ /JC0.2009.25.9630, indexed in Pubmed: 20212251.

32. Robak T, Bloński JZ, Kasznicki M, et al. Cladribine with prednisone versus chlorambucil with prednisone as first-line therapy in chronic lymphocytic leukemia: report of a prospective, randomized, multicenter trial. Blood. 2000; 96(8): 2723-2729, indexed in Pubmed: 11023504.

33. Jamroziak K, Grzybowska-Izydorczyk 0, Jesionek-Kupnicka D, et al. Poor prognosis of Hodgkin variant of Richter transformation in chronic lymphocytic leukemia treated with cladribine. Br J Haematol. 2012; 158(2): 286-288, doi: 10.1111/j.1365-2141.2012.09127.x, indexed in Pubmed: 22500554.

34. Kalinka-Warzocha E, Wajs J, Lech-Maranda E, et al. Polish Lymphoma Research Group. Randomized comparison of cladribine alone or in combination with cyclophosphamide, and cyclophosphamide, vincristine and prednisone in previously untreated low-grade B-cell non-Hodgkin lymphoma patients: final report of the Polish Lymphoma Research Group. Cancer. 2008; 113(2): 367-375, doi: 10.1002/ /cncr.23558, indexed in Pubmed: 18470902.

35. Walewski J, Paszkiewicz-Kozik E, Michalski W, et al. First-line R-CVP versus R-CHOP induction immunochemotherapy for indolent lymphoma with rituximab maintenance. A multicentre, phase III randomized study by the Polish Lymphoma Research Group PLRG4. Br J Haematol. 2020; 188(6): 898-906, doi: 10.1111/bjh.16264, indexed in Pubmed: 31792945.

36. Walewski J, Kraszewska E, Mioduszewska 0, et al. Polish Lymphoma Research Group. Rituximab (Mabthera, Rituxan) in patients with recurrent indolent lymphoma: evaluation of safety and efficacy in a multicenter study. Med Oncol. 2001; 18(2): 141-148, doi: 10.1385/ /mo:18:2:141, indexed in Pubmed: 11778760.

37. Jurczak W, Hubalewska-Dydejczyk A, Giza A, et al. Radioimmunotherapy in follicular lymphomas, a retrospective analysis of the Polish Lymphoma Research Group's (PLRG) experience. Nucl Med Rev Cent East Eur. 2007; 10(2): 91-97, indexed in Pubmed: 18228213.

38. Bednaruk-Młyński E, Pieńkowska J, Skórzak A, et al. Comparison of positron emission tomography/computed tomography with classical contrast-enhanced computed tomography in the initial staging of Hodgkin lymphoma. Leuk Lymphoma. 2015; 56(2): 377-382, doi: 10.3109/10428194.2014.919635, indexed in Pubmed: 24794802.

39. Zaucha JM, Malkowski B, Chauvie S, et al. The predictive role of interim PET after the first chemotherapy cycle and sequential evaluation of response to ABVD in Hodgkin's lymphoma patients-the Polish Lymphoma Research Group (PLRG) Observational Study. Ann Oncol. 2017; 28(12): 3051-3057, doi: 10.1093/annonc/mdx524, indexed in Pubmed: 28950332.

40. Knopińska-Posłuszny W, Kulikowski W, Paszkiewicz-Kozik E, et al. The use of bendamustine with gemcitabine and dexamethasone in the treatment of primary resistant and relapsed Hodgkin's lymphoma a multicentre observational study of the Polish Lymphoma Research Group (PLRG) . Acta Haematol Pol. 2015; 46(Suppl): 58-9.

41. Jurczak W, Ochrem B, Giza A, et al. Role of rituximab in the first-line therapy of high-risk diffuse large B-cell lymphoma: a retrospective analysis by the
Polish Lymphoma Research Group. Pol Arch Med Wewn. 2015; 125(10): 741-748, doi: 10.20452/pamw.3113, indexed in Pubmed: 26334344.

42. Jurczak W, Szmit S, Sobociński M, et al. Premature cardiovascular mortality in lymphoma patients treated with (R)-CHOP regimen a national multicenter study. Int J Cardiol. 2013; 168(6): 5212-5217, doi: 10.1016/j.ijcard.2013.08.033, indexed in Pubmed: 23998543.

43. Szmit S, Jurczak W, Zaucha JM, et al. Pre-existing arterial hypertension as a risk factor for early left ventricular systolic dysfunction following (R)-CHOP chemotherapy in patients with lymphoma. J Am Soc Hypertens. 2014; 8(11): 791-799, doi: 10.1016/j.jash.2014.08.009, indexed in Pubmed: 25455004.

44. Długosz-Danecka M, Gruszka AM, Szmit S, et al. Primary cardioprotection reduces mortality in lymphoma patients with increased risk of anthracycline cardiotoxicity, treated by R-CHOP regimen. Chemotherapy. 2018; 63(4): 238-245, doi: 10.1159/000492942, indexed in Pubmed: 30372698.

45. Drozd-Sokolowska J, Zaucha JM, Biecek P, et al. Type 2 diabetes mellitus compromises the survival of diffuse large B-cell lymphoma patients treated with (R)-CHOP - the PLRG report. Sci Rep. 2020; 10(1): 3517, doi: 10.1038/s41598-020-60565-7, indexed in Pubmed: 32103128.

46. Długosz-Danecka M, Hus I, Puła B, et al. Pixantrone, etoposide, bendamustine, rituximab (P[R]EBEN) as an effective salvage regimen for relapsed/refractory aggressive non-Hodgkin lymphoma-Polish Lymphoma Research Group real-life analysis. Pharmacol Rep. 2019; 71(3): 473-477, doi: 10.1016/j.pharep.2019.02.001, indexed in Pubmed: 31003160.

47. Robak T, Jamroziak K, Gora-Tybor J, et al. Cladribine in a weekly versus daily schedule for untreated active hairy cell leukemia: final report from the Polish Adult Leukemia Group (PALG) of a prospective, randomized, multicenter trial. Blood. 2007; 109(9): 3672-3675, doi: 10.1182/blood-2006-08-042929, indexed in Pubmed: 17209059.

48. Robak T, Błasińska-Morawiec M, Krykowski E, et al. 2-chlorodeoxyadenosine (2-CdA) in 2-hour versus 24-hour intravenous infusion in the treatment of patients with hairy cell leukemia. Leuk Lymphoma. 1996; 22(1-2): 107-111, doi: 10.3109/10428199609051736, indexed in Pubmed: 8724536.

49. Czyz A, Romejko-Jarosinska J, Helbig G, et al. Autologous stem cell transplantation as consolidation therapy for patients with peripheral T cell lymphoma in first remission: long-term outcome and risk factors analysis. Ann Hematol. 2013; 92(7): 925-933, doi: 10.1007/s00277013-1716-2, indexed in Pubmed: 23471671.

50. Maciejka-Kemblowska L, Chaber R, Wrobel G, et al. Clinical features and treatment outcomes of peripheral T-cell lymphoma in children. A current data report from Polish Pediatric Leukemia/Lymphoma Study Group (PPLLSG). Adv Med Sci. 2016; 61(2): 311-316, doi: 10.1016/j.advms.2016.03.002, indexed in Pubmed: 27254421.

51. Hermine 0, Hoster E, Walewski J, et al. European Mantle Cell Lymphoma Network. Addition of high-dose cytarabine to immunochemotherapy before autologous stem-cell transplantation in patients aged 65 years or younger with mantle cell lymphoma (MCL Younger): a randomised, open-label, phase 3 trial of the European Mantle Cell Lymphoma Network. Lancet. 2016; 388(10044): 565-575, doi: 10.1016/ /S0140-6736(16)00739-X, indexed in Pubmed: 27313086.

52. Kluin-Nelemans HC, Hoster E, Hermine 0 , et al. Treatment of older patients with mantle-cell lymphoma. N Engl J Med. 2012; 367(6): 520531, doi: 10.1056/NEJMoa1200920, indexed in Pubmed: 22873532.

53. Kluin-Nelemans HC, Hoster E, Hermine 0, et al. Treatment of older patients with mantle cell lymphoma (MCL): long-term follow-up of the randomized European MCL elderly trial. J Clin Oncol. 2020; 38(3): 248256, doi: 10.1200/JC0.19.01294, indexed in Pubmed: 31804876. 
54. Mead GM, Sydes MR, Walewski J, et al. UKLG LY06 collaborators. An international evaluation of CODOX-M and CODOX-M alternating with IVAC in adult Burkitt's lymphoma: results of United Kingdom Lymphoma Group LYO6 study. Ann Oncol. 2002; 13(8): 1264-1274, doi: 10.1093/annonc/mdf253, indexed in Pubmed: 12181251.

55. Hoelzer D, Walewski J, Döhner H, et al. German Multicenter Study Group for Adult Acute Lymphoblastic Leukemia. Improved outcome of adult Burkitt lymphoma/leukemia with rituximab and chemotherapy: report of a large prospective multicenter trial. Blood. 2014; 124(26): 3870-3879, doi: 10.1182/blood-2014-03-563627, indexed in Pubmed: 25359988.

56. Sokolowska-Wojdylo M, Florek A, Zaucha JM, et al. Polish Lymphoma Research Group experience with bexarotene in the treatment of cutaneous T-cell lymphoma. Am J Ther. 2016; 23(3): e749-e756, doi: 10.1097/MJT.00000000000000056, indexed in Pubmed: 24732904.

57. lżykowska K, Rassek K, Żurawek M, et al. Hypomethylation of the promoter region drives ectopic expression of TMEM244 in Sézary cells. J Cell Mol Med. 2020; 24(18): 10970-10977, doi: 10.1111/ /jcmm.15729, indexed in Pubmed: 32794659.

58. Olszewska B, Żawrocki A, Lakomy J, et al. Mapping signal transducer and activator of transcription (STAT) activity in different stages of mycosis fungoides and Sezary syndrome. Int J Dermatol. 2020; 59(9): 1106-1112, doi: 10.1111/ijd.15036, indexed in Pubmed: 32643174.

59. Sokołowska-Wojdyło M, Blażewicz I, Olszewska B, et al. Phase $1 \mathrm{~b}$ study evaluating the safety and efficacy of topical administration of WP1220, a STAT3 inhibitor, for mycosis fungoides (MF). $4^{\text {th }}$ World Congress of Cutaneous Lymphomas (abstract). Barcelona, 2020.

60. Dmoszynska A, Walter-Croneck A, Hus I, et al. The efficacy and safety of the low-thalidomide dose CTD (cyclophosphamide, thalidomide, dexamethasone) regimen in patients with multiple myeloma - a report by the Polish Myeloma Study Group. Leuk Res. 2010; 34(10): 1330-1335, doi: 10.1016/j.leukres.2010.05.003, indexed in Pubmed: 20627385.

61. Usnarska-Zubkiewicz L, Dębski J, Butrym A, et al. Efficacy and safety of lenalidomide treatment in multiple myeloma (MM) patients - Report of the Polish Myeloma Group. Leuk Res. 2016; 40: 90-99, doi: 10.1016/j.leukres.2015.11.005, indexed in Pubmed: 26626207.

62. Charlinski G, Grzasko N, Jurczyszyn A, et al. The efficacy and safety of pomalidomide in relapsed/refractory multiple myeloma in a "real-world" study: Polish Myeloma Group experience. Eur J Haematol. 2018; 101(3): 354-361, doi: 10.1111/ejh.13106, indexed in Pubmed: 29882602.

63. Grzasko N, Hajek R, Hus M, et al. Chromosome 1 amplification has similar prognostic value to del(17p13) and $t(4 ; 14)(p 16 ; q 32)$ in multiple myeloma patients: analysis of real-life data from the Polish Myeloma Study Group. Leuk Lymphoma. 2017; 58(9): 1-15, doi: 10.1080/10428194.2016.1272684, indexed in Pubmed: 28092996.

64. Walter-Croneck A, Grzasko N, Soroka-Wojtaszko M, et al. Case-adjusted bortezomib-based strategy in routine therapy of relapsed/refractory multiple myeloma shown to be highly effective - a report by Polish Myeloma Study Group. Leuk Res. 2014; 38(7): 788-794, doi: 10.1016/j.leukres.2014.04.011, indexed in Pubmed: 24862794.

65. Hus I, Mańko J, Jawniak D, et al. High efficacy and safety of VTD as an induction protocol in patients with newly diagnosed multiple myeloma eligible for high dose therapy and autologous stem cell transplantation: A report of the Polish Myeloma Study Group. Oncol Lett. 2019; 18(6): 5811-5820, doi: 10.3892/ol.2019.10929, indexed in Pubmed: 31788054.
66. Giannopoulos K, Jamroziak K, Usnarska-Zubkiewicz L, et al. Recommendations of Polish Myeloma Group concerning diagnosis and therapy of multiple myeloma and other plasmacytic dyscrasias for 2018/2019. Acta Haematol Pol. 2018; 49: 157-206, doi: doi. org/10.2478/ahp-2018-0024.

67. Szpiczak plazmocytowy. Ocena jakości informacyjnej rejestru kontraktowego. https://zdrowedanenfzgovpl/course/viewphp? (October 20, 2020).

68. Jurczyszyn A, Grzasko N, Gozzetti A, et al. Central nervous system involvement by multiple myeloma: a multi-institutional retrospective study of 172 patients in daily clinical practice. Am J Hematol. 2016; 91(6): 575-580, doi: 10.1002/ajh.24351, indexed in Pubmed: 26955792.

69. Jurczyszyn A, Radocha J, Davila J, et al. Prognostic indicators in primary plasma cell leukaemia: a multicentre retrospective study of 117 patients. Br J Haematol. 2018; 180(6): 831-839, doi: 10.1111/ /bjh.15092, indexed in Pubmed: 29315478.

70. Jurczyszyn A, Castillo JJ, Avivi I, et al. Secondary plasma cell leukemia: a multicenter retrospective study of 101 patients. Leuk Lymphoma. 2019; 60(1): 118-123, doi: 10.1080/10428194.2018.1473574, indexed in Pubmed: 29965787.

71. Jurczyszyn A, Waszczuk-Gajda A, Castillo JJ, et al. Primary refractory multiple myeloma: a real-world experience with 85 cases. Leuk Lymphoma. 2020; 61(12): 2868-2875, doi: 10.1080/ /10428194.2020.1788014, indexed in Pubmed: 32623944.

72. Goldman-Mazur S, Jurczyszyn A, Castillo JJ, et al. A multicenter retrospective study of 223 patients with $\mathrm{t}(14 ; 16)$ in multiple myeloma. Am J Hematol. 2020; 95(5): 503-509, doi: 10.1002/ajh.25758, indexed in Pubmed: 32072687.

73. Jurczyszyn A, Gozzetti A, Gdula-Argasińska J, et al. Similar survival outcomes in patients with biclonal versus monoclonal myeloma: a multi-institutional matched case-control study. Ann Hematol. 2017; 96(10): 1693-1698, doi: 10.1007/s00277-017-3084-9, indexed in Pubmed: 28766002.

74. Jurczyszyn A, Nahi H, Avivi I, et al. Characteristics and outcomes of patients with multiple myeloma aged 21-40 years versus $41-60$ years: a multi-institutional case-control study. Br J Haematol. 2016; 175(5): 884-891, doi: 10.1111/bjh.14328, indexed in Pubmed: 27682187.

75. Giebel S, Kruzel T, Czerw T, et al. Intermediate-dose Ara-C plus G-CSF for stem cell mobilization in patients with lymphoid malignancies, including predicted poor mobilizers. Bone Marrow Transplant. 2013; 48(7): 915-921, doi: 10.1038/bmt.2012.269, indexed in Pubmed: 23292239.

76. Giebel S, Sadus-Wojciechowska M, Halaburda K, et al. Increased efficacy of intermediate-dose cytarabine + G-CSF compared to DHAP + G-CSF for stem cell mobilization in patients with lymphoma: an analysis by the polish lymphoma research group. Ann Hematol. 2016; 95(2): 263-269, doi: 10.1007/s00277-015-2557-y, indexed in Pubmed: 26611854 .

77. Czerw T, Sadus-Wojciechowska M, Michalak K, et al. Increased efficacy ofstem cell chemomobilization with intermediate-dose cytarabine plus granulocyte colony-stimulating factor (G-CSF) compared with G-CSF alone in patients with multiple myeloma: results of a randomized trial. Biol Blood Marrow Transplant. 2019; 25(2): 248-255, doi: 10.1016/j.bbmt.2018.09.023, indexed in Pubmed: 30266677.

78. Giebel S, Locatelli F, Lamparelli T, et al. Survival advantage with KIR ligand incompatibility in hematopoietic stem cell transplantation from unrelated donors. Blood. 2003; 102(3): 814-819, doi: 10.1182/ /blood-2003-01-0091, indexed in Pubmed: 12689936. 
79. Karabon L, Wysoczanska B, Bogunia-Kubik K, et al. IL-6 and IL-10 promoter gene polymorphisms of patients and donors of allogeneic sibling hematopoietic stem cell transplants associate with the risk of acute graft-versus-host disease. Hum Immunol. 2005; 66(6): 700-710, doi: 10.1016/j.humimm.2005.02.003, indexed in Pubmed: 15993715.

80. Giebel S, Labopin M, Ibatici A, et al. Acute Leukemia Working Party of the European Group for Blood and Marrow Transplantation. Association of Human Development Index with rates and outcomes of hematopoietic stem cell transplantation for patients with acute leukemia. Blood. 2010; 116(1): 122-128, doi: 10.1182/ /blood-2010-01-266478, indexed in Pubmed: 20395416.

81. Styczynski J, Gil L, Tridello G, et al. Infectious Diseases Working Party of the European Group for Blood and Marrow Transplantation. Response to rituximab-based therapy and risk factor analysis in Epstein Barr Virus-related lymphoproliferative disorder after hematopoietic stem cell transplant in children and adults: a study from the Infectious Diseases Working Party of the European Group for Blood and Marrow Transplantation. Clin Infect Dis. 2013; 57(6): 794-802, doi: 10.1093/ /cid/cit391, indexed in Pubmed: 23771985.

82. Styczynski J, Reusser P, Einsele H, et al. Second European Conference on Infections in Leukemia. Management of HSV, VZV and EBV infections in patients with hematological malignancies and after SCT: guidelines from the Second European Conference on Infections in Leukemia. Bone Marrow Transplant. 2009; 43(10): 757-770, doi: 10.1038/bmt.2008.386, indexed in Pubmed: 19043458.

83. Penack 0 , Marchetti M, Ruutu T, et al. Prophylaxis and management of graft versus host disease after stem-cell transplantation for haematological malignancies: updated consensus recommendations of the European Society for Blood and Marrow Transplantation. Lancet Haematol. 2020; 7(2): e157-e167, doi: 10.1016/S2352-3026(19)30256-X, indexed in Pubmed: 32004485.

84. Czyżewski K, Styczyński J, Giebel S, et al. for Polish Society of Pediatric Oncology and Hematology and Polish Society of Hematology and Blood Transfusion. Age-dependent determinants of infectious complications profile in children and adults after hematopoietic cell transplantation: lesson from the nationwide study. Ann Hematol. 2019; 98(9): 2197-2211, doi: 10.1007/s00277-019-03755-2, indexed in Pubmed: 31321454.

85. Waszczuk-Gajda A, Drozd-Sokołowska J, Basak GW, et al. Infectious complications in patients with multiple myeloma after high-dose chemotherapy followed by autologous stem cell transplant: Nationwide Study of the Infectious Complications Study Group of the Polish Adult Leukemia Group. Transplant Proc. 2020; 52(7): 2178-2185, doi: 10.1016/j. transproceed.2020.02.068, indexed in Pubmed: 32217016.

86. Styczyński J, Czyżewski K, Frączkiewicz J, et al. Clinical spectrum and outcome of invasive mucormycosis in children and adults: Polish experience of the decade 2010-2019. Acta Haematol Pol. 2020; 51(3): 157-163, doi: 10.2478/ahp-2020-0028.

87. Hus I, Piekarska A, Roliński R, et al. Vaccination of adult patients with hematological malignancies and patients with asplenia - guidelines of PTHiT and Infectious Diseases Working Group PALG. Acta Haematol Pol. 2018; 49(3): 93-101, doi: 10.2478/ahp-2018-0016.

88. Piekarska A, Giebel S, Basak G, et al. Szczepienia ochronne u chorych dorosłych po przeszczepieniu komórek krwiotwórczych - zalecenia sekcji do spraw zakażeń PALG. Acta Haematol Pol. 2017; 48(1): 1-9, doi: 10.1016/j.achaem.2017.01.003.

89. Kołtan S, Urbańczyk A, Grześk E, et al. Vaccinations in children during and after oncological treatment and in selected hematological diseases: recommendations of the Polish Society of Pediatric Oncol- ogy and Hematology. Acta Haematol Pol. 2019; 50(4): 182-91, doi: 10.2478/ahp-2019-0030 .

90. Gil L, Kałwak K, Piekarska A, et al. Antifungal management in adults and children with hematological malignancies or undergoing hematopoietic cell transplantation: recommendations of Polish Society of Hematology and Blood Transfusion, Polish Society of Pediatric Oncology and Hematology, and Polish Adult Leukemia Study Group, 2020. Acta Haematol Pol. 2020; 51(2): 60-72, doi: 10.2478/ahp-2020-0014.

91. Styczyński J. Prophylaxis vs preemptive therapy in prevention of CMV infection: new insight on prophylactic strategy after allogeneic hematopoietic cell transplantation. Acta Haematol Pol. 2020; 51(1): 17-23, doi: 10.2478/ahp-2020-0005.

92. Styczyński J. Infections following CAR-T cells therapy: current state-of-the-art review and recommendations. Acta Haematol Pol. 2020; 51(1): 11-16, doi: 10.2478/ahp-2020-0004.

93. Szumera-Cieckiewicz A, Galazka K, Szpor J, et al. Distribution of lymphomas in Poland according to World Health Organization classification: analysis of 11718 cases from National Histopathological Lymphoma Register project - the Polish Lymphoma Research Group study. Int J Clin Exp Pathol. 2014; 7(6): 3280-3286, indexed in Pubmed: 25031749.

94. Szumera-Ciećkiewicz A, Wojciechowska U, Didkowska J, et al. Population-based epidemiological data of follicular lymphoma in Poland: 15 years of observation. Sci Rep. 2020; 10(1): 14610, doi: 10.1038/ /s41598-020-71579-6, indexed in Pubmed: 32884080.

95. Szumera-Ciećkiewicz A, Rymkiewicz G, Grygalewicz B, et al. Comprehensive histopathological diagnostics of aggressive B-cell lymphomas based on the updated criteria of the World Health Organisation's 2017 classification. Pol J Pathol. 2018; 69(1): 1-19, doi: 10.5114/ /pjp.2018.75332, indexed in Pubmed: 29895122.

96. Lewandowski K, Warzocha K, Hellmann A, et al. Frequency of BCR-ABL gene mutations in Polish patients with chronic myeloid leukemia treated with imatinib: a final report of the MAPTEST study. Pol Arch Med Wewn. 2009; 119(12): 789-794, indexed in Pubmed: 20010464.

97. Kjaer L, Skov V, Andersen MT, et al. Variant-specific discrepancy when quantitating BCR-ABL1 e13a2 and e14a2 transcripts using the Europe Against Cancer qPCR assay. Eur J Haematol. 2019; 103(1): 26-34, doi: 10.1111/ejh.13238, indexed in Pubmed: 30985947.

98. Asp J, Skov V, Bellosillo B, et al. International external quality assurance of JAK2 V617F quantification. Ann Hematol. 2019; 98(5): 1111-1118, doi: 10.1007/s00277-018-3570-8, indexed in Pubmed: 30535576.

99. Link-Lenczowska D, Pallisgaard N, Cordua S, et al. A comparison of qPCR and ddPCR used for quantification of the JAK2 V617F allele burden in Ph negative MPNs. Ann Hematol. 2018; 97(12): 2299-2308, doi: 10.1007/s00277-018-3451-1, indexed in Pubmed: 30056580.

100. Luczak M, Kaźmierczak M, Handschuh L, et al. Comparative proteome analysis of acute myeloid leukemia with and without maturation. J Proteomics. 2012; 75(18): 5734-5748, doi: 10.1016/j. jprot.2012.07.030, indexed in Pubmed: 22850270.

101. Handschuh L, Kaźmierczak M, Milewski MC, et al. Gene expression profiling of acute myeloid leukemia samples from adult patients with AML-M1 and -M2 through boutique microarrays, real-time PCR and droplet digital PCR. Int J Oncol. 2018; 52(3): 656-678, doi: 10.3892/ /ijo.2017.4233, indexed in Pubmed: 29286103.

102. Nagler A, Baron F, Labopin M, et al. Measurable residual disease (MRD) testing for acute leukemia in EBMT transplant centers: a survey on behalf of the ALWP of the EBMT. Bone Marrow Transplant. 2021; 56(1): 218-224, doi: 10.1038/s41409-020-01005-y, indexed in Pubmed: 32724200. 